\title{
Introduction: Islamic Finance and Contemporary Challenges
}

Islamic finance is a concept that, irrespective of one's religious convictions, has gained momentum and been accepted around the world today. Its development and resilience, in light of the recent financial crises and on-going unprecedented pandemic, has not only confirmed its practical benefits but also untapped its potential. However, it is also clear that the numerous challenges which it still faces are reasons why Islamic finance has yet to enjoy the benefit of its full potential. Understanding the nature of such challenges must be the first step towards their resolve, as it would be impossible to prescribe an appropriate medication without first diagnosing the disease. In this regard, we are strongly confident that the ongoing development of Islamic finance can be facilitated via further academic research and the publication of such findings. ${ }^{1}$

Understanding its historical context is important to resolve Islamic finance challenges. The classical notion that Islamic finance is limited to Islamic commercial finance only needs to be both broadened and institutionalised by accepting that Islamic finance indeed has two branches: namely, Islamic commercial finance as well as Islamic social finance. In this way, it will be possible to achieve financial inclusion without marginalising any segment of the population on the grounds that they are 'unbankable'. The word 'unbankable' would have no significance if both Islamic commercial finance and Islamic social finance could be housed under one roof. The ways in which to achieve this goal need to be researched and implemented. Moreover, in this modern era, Islamic finance cannot operate without technology. Investment in technology is not only important in itself, but we also need to understand the ways in which technology and Islamic finance can be integrated to use the available resources in the best possible manner. Furthermore, there is also a need to redefine Islamic finance in light of maqāṣid al-sharíah, or the objectives of

1 M. Kabir Hassan \& Aishath Muneeza, Need to Redefine Islamic Finance in the Light of Maqāṣid al-Sharīah, Working Paper, July 2020, University of New Orleans; Umar Oseni, M. Kabir Hassan \& Nazim Ali, 'Judicial support for the Islamic financial services industry: Towards reform-oriented interpretive approaches', Arab Law Quarterly, forthcoming 2021. 
Islamic law, whereby the objective of Islamic finance should be more than simply achieving the status of Sharīah compliance for its products and services. An objective of Islamic finance should also be the elimination of dangers and harm threatening humankind by promoting activities that will be beneficial for society as well as the environment. The impact of the financial institution's economic activities ought to be given paramount consideration, but not to the detriment of the social order as a result.

Last but not least, experience to date demonstrates that Islamic finance cannot continue to operate in a conventional economy in which even conventional monetary tools have become incompatible with Islamic finance. The time has come to strive towards creating a full-fledged Islamic economy. However, in this regard, the challenge must begin by visualising a concept for an Islamic economy itself and by seeking the political will required for its realisation.

The focus of this special issue of the Arab Law Quarterly is on the important theme 'Islamic finance and contemporary challenges', to be deliberated and discussed to take the Islamic finance industry to the next level. It is anticipated that, in light of the articles published in this special issue, imperative studies on Islamic finance will be presented from the perspective of experts in the field, who have contributed immensely to the development of the Islamic finance industry either by sharing knowledge or practice or both. This special issue contains nine contributions, each of which has been selected via a blindpeer review process from amongst numerous papers submitted.

To shape the future of an Islamic finance industry, it is imperative to understand the types of economic systems found in the history of Muslim civilisations. These features will help the current generation comprehend the practical aspects of Islamic economics and hopefully help determine the way forward when implementing a revised Islamic economic system. Murat Çizakça, in his article entitled 'Economic Systems of Muslims in History', argues that during its long history, the Islamic world experienced three different economic systems. The original Islamic economy that was introduced by the Qurān and other classical sources of Islam was a form of sui generis, commercial, pre-industrial and ethical capitalism. He presents evidence for this from the classical sources of Islam, as well as from the history of Islamic economic thought.

In recent years, it has been argued that Sharīah-compliant products ought to be Sharīah-based rather than Sharīah-compliant. From an ethical point of view, Ryan Calder deliberates this issue in 'Sharīah-compliant or 
Sharīah-based? The Changing Ethical Discourse of Islamic Finance', where he argues that the mere achievement of Sharīah compliance should not be the sole objective of Islamic finance, but instead, should go beyond that. Furthermore, by referring to the history of the emergence of the two terms, 'Sharīah-compliance' and 'Sharīah- based', Calder argues that Islamic finance ought to align its practices by considering the ethical dimension of its actions.

As learning from historical context is relevant, to bridge the history and contemporary developments of Islamic finance, Valentino Cattelan has shed light on Sharīah-compliance and securitisation in 'The Typewritten Market: Sharī'ah-Compliance and Securitisation in the Law of Islamic Finance', producing evidence to show that Islamic finance is a radical shift in the social anthropology of Islamic law from classical to contemporary times. He highlights the changes from figh in medieval trade (where individual actions were judged by rules legitimised by their local context) to the current process of Sharīah-compliance and argues that this process belongs to a textual polity where standardised certificates, contracts and securities have replaced actual social relations in the global financial market. Cattelan uses the notion of a 'typewritten market' to depict the nature of Islamic finance as a socioeconomic space embodying a 'de-materialised Šarīah', which he describes as the Islamic law whose contemporary time belongs more to legal/financial technology rather than to Muslim human action.

There is no uniform process to be followed in determining a Sharīahcompliance status of an Islamic finance contract. Depending on the legal, regulatory and governance framework of the country to regulate Islamic finance, the necessary process to determine this should include the required procedure. In 'Flexibility and Sharīah Compliance of Islamic Financial Contracts: An Evaluative Framework', Tareq Moqbel and Habib Ahmed present an evaluative framework to determine Sharīah compliance of Islamic financial contracts. Moreover, they also allude to the important issue of flexibility of contracts by using Islamic legal theory. They use the evaluative framework to assess the Sharīah compliance of a real-life mudärabah (silent partnership) contract.

Various types of penalty clauses inserted into Islamic finance contracts increase the agreed-upon price due to non-payment of the receivable amount to the financial institution on time. Faiza Ismail argues in 'Murābahah Penalty Clause is Riba $\bar{a}$ in Disguise! The Penalty Clause Questions the Deep-Rooted Preference for Literal Interpretation over Substantial Interpretation of Riba', that the penalty clause is riba in disguise. Ismail evaluates the application of the penalty clause in the context of murābahah, using the courts in Pakistan as example, which have never enforced a penalty clause in a murābahah contract. 
She concludes that the literal interpretation based on the objective of Sharīah (substantial interpretation) will prevent loopholes such as the abuse of the murābahah instrument.

In Islamic finance, not all Sharī'ah contracts that are used today are derived from the classical practice as contracts have been evolving over time as per the requirement of the people living today. In 'Explaining the Modern Transformation of Islamic Legal Contracts: Theoretical and Practical Implications', Ismail Cebeci explains the modern transformation of Islamic legal contracts with its theoretical and practical implications. He examines changing contexts and factors which cause transformation as well as shows their effects on Islamic finance contracts by presenting general theories in terms of modern ijtihād (independent reasoning) on modern Islamic finance contracts. He argues that modern Islamic finance contracts have been transformed by the effects of changing factors and contexts. In this regard, his deliberations helps us to appreciate the flexibility of Sharīah in catering to human needs.

Living in industry 4.0 provides the opportunity to live with innovations that could never previously have been anticipated. The emergence of blockchain technology, heralded the dawn of the bitcoin and cryptocurrency era. However, the opinions of Shari'ah scholars were not uniform with regard to the validity of their usage from a Sharīah perspective. In their article, 'A Conventional and Sharīaah Analysis of Bitcoin', M. Kabir Hassan, Mohammad Sydul Karim and Aishath Muneeza analyse bitcoins and cryptocurrencies from conventional and Sharīah perspectives. They conclude that there is division on the matter among stakeholders, including conventional and Sharīah scholars, and they recommend inter alia to conduct further research on ways in which Sharī'ah-compliant cryptocurrencies could be adopted worldwide.

In recent years, șukūk default and its restructuring has become an important issue worthy of discussion. The on-going unprecedented pandemic has also shown the importance of restructuring of șukük such as other financial instruments in case of default. Unlike a conventional bond, șukūk restructuring could be a difficult and complex process depending on the type of șukük structure used or adopted in the transaction. Rafisah Mat Radzi discusses this important issue in 'Different Structure, Neither Debt nor Equity: What Should Be the Approaches for Restructuring Șukūk (Islamic Bonds) Default?'. He argues that $s ̦ k \bar{u} k$ is a unique product — neither a debt nor an equity—and concludes that the contingent approaches such as extending maturity, haircut and debtequity swap are based on the classification of șukūk structures and require a case-by-case approach in șukūk restructuring in case of default. 
In any jurisdiction that wishes to establish and sustain Islamic finance, having a proper regulatory and supervisory framework is important. Since there is no such uniform framework that fits all jurisdictions, a case study approach is important to understand the role of a regulatory and supervisory framework in the development of Islamic finance. Shamsalden Aziz Salh and Mark Hyland present a critical evaluation in their article, 'Sharīah Regulation and Supervision of the Iraqi Islamic Banking System', presenting the challenges facing the development of Islamic banking in Iraq with the objective of resolving them in the future. To this end, they compare the Sharīah regulatory and supervisory system for Islamic banking in Iraq with the systems of Bahrain and Malaysia.

\title{
3 Conclusions
}

The institutionalisation of Islamic finance and its growth worldwide over the years prove that Islamic finance is here to stay. To shape the future of the Islamic finance industry, strategic planning for the future is necessary. This will only be possible when we understand the history of the industry, with all the reasons for the mistakes or glitches that occurred, and then set out with the intention to avoid their repetition or to eliminate similar problems in the future. Hopefully, this special issue of the Arab Law Quarterly will assist in realising this goal.

\section{Guest Editor}

\author{
M. Kabir Hassan \\ Professor of Finance, Hibernia Professor of Economics and Finance, Bank \\ One Professor in Business, Hancock Whitney Bank Professor of Economics, \\ Department of Economics and Finance, University of New Orleans, New \\ Orleans, LA, USA \\ mhassan@uno.edu
}

